\title{
Samuel Thomas Soemmerring (1755-1830): The Naming of Cranial Nerves
}

\author{
John M.S. Pearce \\ Emeritus Consultant Neurologist, Department of Neurology, Hull Royal Infirmary, Hull, UK
}

\section{Keywords}

Soemmerring $\cdot$ Cranial nerves $\cdot$ Macula $\cdot$ Telegraph

\section{Abstract}

Samuel Thomas Soemmerring was a Prussian polymathic doctor with remarkable achievements in anatomy, draftsmanship and inventions. His naming of 12 pairs of cranial nerves in his graduation thesis is of particular importance. Healso gave original descriptions of the macula, sensory pathways and of the substantia nigra. His non-medical contributions were diverse and included criticism of the guillotine, invention of a telegraphic system, and discoveries in palaeontology.

(c) 2017 S. Karger AG, Basel

\section{Introduction}

The expression, "Renaissance Man" applies to Samuel Thomas Soemmerring (Fig. 1) one of the great anatomists of the late 18th and 19th centuries [1]. He was born at Thorn, in East Prussia (now Torun in Poland) in January 1755. His father, Johann Thomas Soemmering, a physician, took him as a child to see autopsies, which we may guess fired his interests in Medicine. At school he showed an unusual skill with words and an enthusiasm for collecting and for drawing. These literary and artistic abilities flowered later in his medical career.

Soemmerring read Medicine at Göttingen, graduating in 1788, stimulated by his teachers who included Ernst Gotfried Baldinger, Heinrich August Wrisberg and Jo-
๑) 2017 S. Karger AG, Basel

E-Mail karger@karger.com www.karger.com/ene

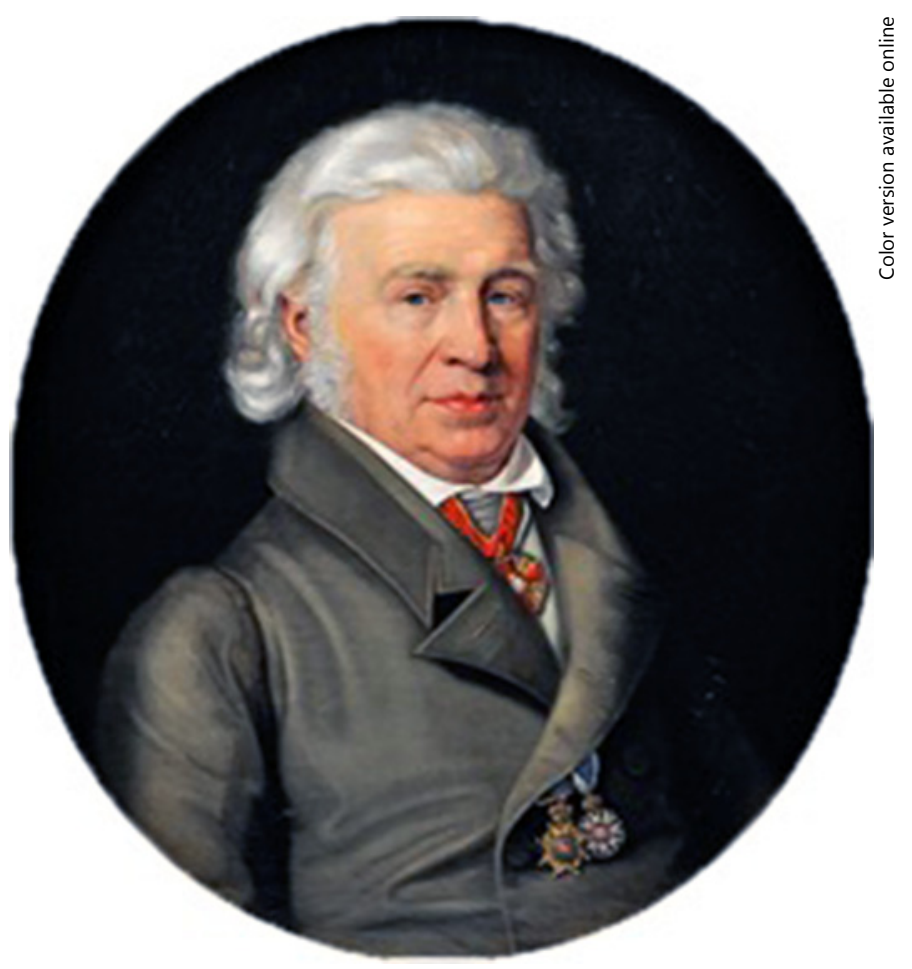

Fig. 1. Samuel Thomas von Soemmerring.

hann Friedrich Blumenbach [2]. He then studied in Holland and visited Britain in 1778, where he met John Hunter, worked briefly with Alexander Monro Secundus in Edinburgh; and importantly for his career, met Georg Forster who aided his appointment to the Chair in Anatomy at Kassel a year later. He was to become Professor at 


\section{SAM. THOM. SOEMMERNNG matcisas becrems}

BASI ENCEPHALI

ORIGINIBUS NERVORUM

CRANIO EGREDIENTIUM

LIBEI QUIAQUE

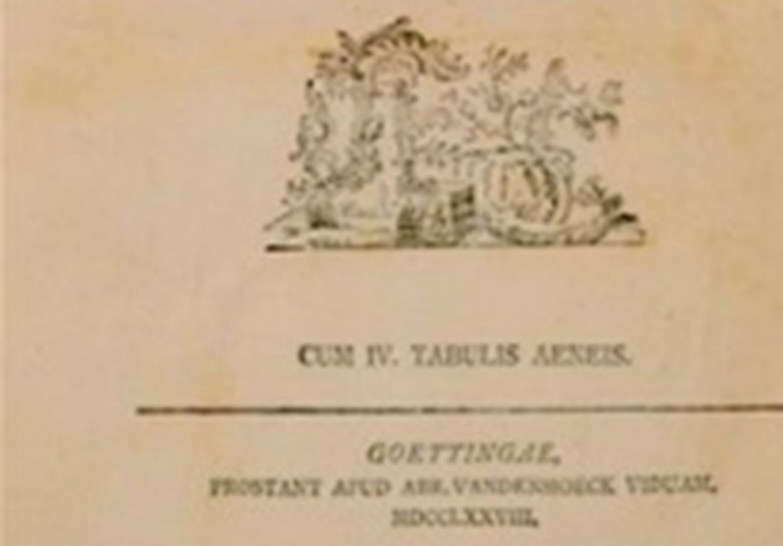

Fig. 2. Soemmerring "on the base of the brain and the origin of the nerves exiting the skull."

the universities of Mainz (1784) and Munich (1805). While pursuing anatomy, he practised as physician in Frankfurt-on-Main, and published a 5-volume textbook of anatomy [3].

\section{Anatomy}

Soemmerring is best remembered for his account of the 12 pairs of cranial nerves in 1778 , which was part of his student's doctoral thesis [4]: Anatomica de basi encephali et originibus nervorum cranio egredientium libri quinqe (On the Base of the Brain and the Origin of the Nerves Exiting the Skull. Five Chapters) (Fig. 2). Until this account, the prevailing view was of 9 pairs of cranial nerves as described by Thomas Willis. It is astonishing that such an important discovery was the work of a student, and it bears testimony to his precocious powers of dissection and observation, not least because it plainly contradicted a long established "fact."

Wrisberg, Soemmerring's teacher, first named 2 separate roots of the 5th nerve, naming them portio major and portio minor. Soemmerring was the first to use the term "nervus abducens" in 1778. Before Soemmerring, the facial and vestibulo-cochlear nerves were considered a single nerve. Soemmerring used the name "nerve of Wrisberg" for the nervus intermedius, in deference to his teacher [5]. Although Haller had described in 1762 the 8th cranial nerves as comprising the glossopharyngeal, vagus, and the spinal accessory nerves, it was Soemmerring who separated the 3 components but retained Haller's nomenclature.

His description brought him instant recognition. It remains valid today [6]. However, Soemmerring thought that the cranial nerves emerged from the ventricular walls. In the medieval tradition, he further believed that the cerebrospinal fluid could be animated and that it was the immediate organ of the soul $[7,8]$, the sensorium commune. Both Goethe and Kant disputed his attempt to localise the soul. Like Descartes he believed the nerves ended in the walls of the ventricle and were stimulated by the flow of ventricular fluid [9].

His interest in the anatomy of the sense organs was stimulated after his discovery of the fovea centralis in the macula lutea. Between 1801 and 1810, he illustrated with copper plate engravings the human sense organs, with descriptions in German and Latin. After Buzzi and Fragonard, Soemmerring's essay [10] described the retinal vessels and the macula lutea. However, he thought that the foveola was a hole or foramen (foraminulum centrale retinae) and related it to the blind spot, which he called the limbus luteus, and which was referred to as "Soemmerring's spot."

Soemmerring identified the black band in the midbrain and in 1778 described the substantia nigra, which was named "Soemmerring's substance" for a time, but this was also described ("tache noire" or "locus niger crurum cerebri") by Vicq d'Azyr as Soemmerring himself acknowledged [11]. He also noted in 1778 the broad line running through the calcarine cortex, which he mistakenly believed antedated the white line of Francesco Gennari's (1750-1797) description of the "white line" in 1776 because Gennari did not publish his results until 1782. The "Illustrations of the sense organs" (1801-1809) demonstrated his researches and interpretation of the sensory pathways that he erroneously connected to the ventricles.

But, Medicine and Anatomy were insufficient fully to occupy him. Outside Medicine he found time to investigate and make significant contributions to palaeontology: demonstrating fossils of the pterodactyls, known as Ptero- 


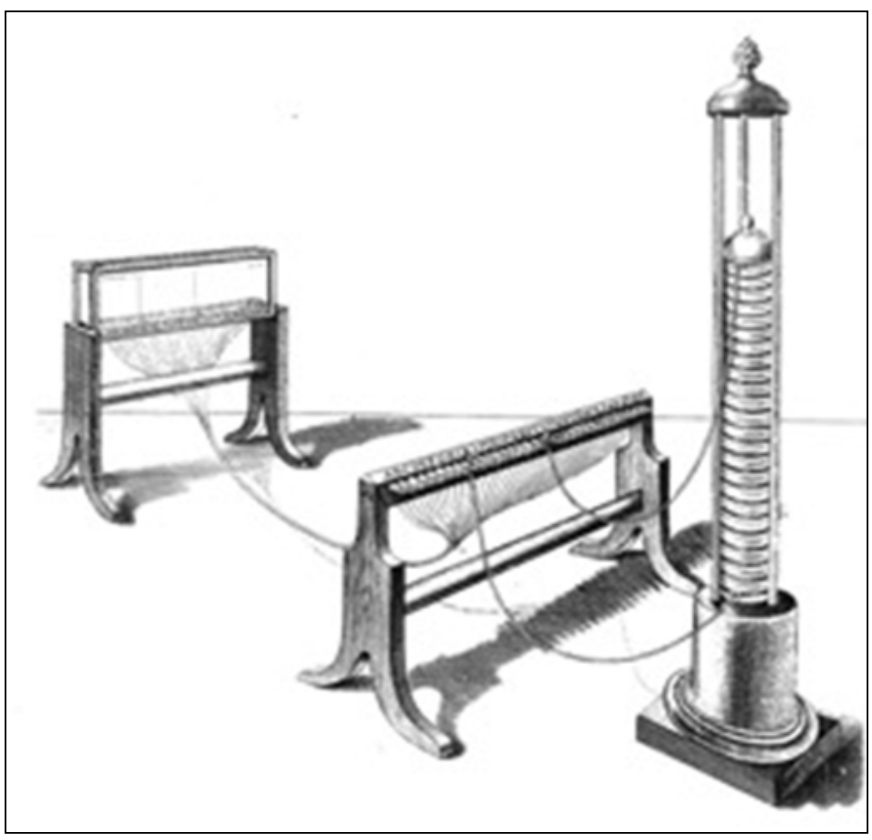

Fig. 3. Soemmerring diagram of telegraphic system.

dactylus antiquus Soemmerring. In later life, his innate curiosity still not spent, he studied sunspots with a telescope given to him by the physicist Joseph von Fraunhofer. Soemmerring played a major role in developing the electrical telegraph in 1809, which he developed in 1811 into the first telegraphic system in Bavaria: a rapid direct system of messages (Fig. 3). This was almost fortuitous because his investigation began in order to occupy his time when the promised anatomy theatre in the Munich Bavarian Academy of Science failed to materialize.

$\mathrm{He}$ was an accomplished artist (influenced by the Leiden anatomical artist Bernhard Siegfried Albinus, 1697-1770), but also an accomplished writer and philosopher, who extensively corresponded, mostly in German or Latin, with Immanuel Kant, Goethe, Friedrich Schelling, with Wilhelm and Alexander von Humboldt, and the French surgeon Jean Dominique Larrey. His friendship with Goethe arose when Goethe showed an interest in comparative osteology, and principally in his investigation into whether humans showed an intermaxillary bone (os intermaxillare), a bone that would establish a direct link with primates and other mammals in which it was present. Goethe found this os intermaxillare in the human foetal skull and observed: "man and beast are related to each other": truly a Darwinian concept.

But controversy did not pass him by. His essay on the organ of the soul, Uber das Organ der Seele in 1796, dedi- cated to Immanuel Kant, was vehemently criticized by both anatomists and philosophers [12]. Soemmerring's idea was that the soul, or sensorium commune - brought together many sensations into a single experience and that it was located in the ventricular cerebrospinal fluid, mediated by the sensory nerves lining the interior of the ventricles.

In his essay on the guillotine (1795), then regarded as a humane form of execution, Soemmerring, using results from his galvanic studies stated that death by decapitation was neither quick nor humane, and that the severed head was still quite capable of feeling.

\section{Legacy}

He was made Knight of the Order of the Civil Service of the Bavarian Crown in 1808 and granted personal nobility, becoming Samuel Thomas von Soemmerring. He died "of old age" in March 1830, aged 75. In 1897, the city of Frankfurt erected a memorial in the city cemetery and in 1862 named a street after him. A bronze monument to Soemmerring stood from 1897 to $1941 / 1942$ in front of the Frankfurt Zoo.

A man of enormous energy and restless curiosity, his medical works were diverse. They included descriptions of the optic chiasm, the pineal body, brain and spinal anatomy, the lungs, the ear, the senses of smell and taste, and embryonic and developmental defects. This list of his work shows that he had to an unusual degree an intuitive faculty for original observation combined with skilful technical talent. The Lancet observed that he showed admirable talent of observation, and indefatigable power of research, which are the most eminent features of Soemmering's genius [13]. His legacy was admirably stated as "one of the outstanding anatomists of this era" by McHenry in Garrison's History of Neurology (1969).

\section{Disclosure Statement}

There are no conflicting interests or financial support in this work.
References
1 Wagner R: Samuel Thomas Soemmerring's Leben und Verkehr mit seinen Zeitgenossen, 2 Vols. Leipzig, 1844.
2 Aminoff MJ, Daroff RB (eds): Encyclopedia of the Neurological Sciences, ed 2. Elsevier, 2014, pp 239-240.
3 Soemmerring ST: Vom Bau des Menschli- chen Körpers, 5 Vols. (Frankfurt/Main, 1791-1796; Latin Trans, Leipzig, 1794-1801).

Samuel Thomas Soemmerring: The Naming of Cranial Nerves 
4 Soemmerring ST: Anatomica de Basi Encephali et Originibus Nervorum Cranio Egredientium Libri Quinque. Göttingen, 1778.

5 Davis MC, Griessenauer CJ, Bosmia AN, Tubbs RS, Shoja MM: The naming of the cranial nerves: a historical review. Clin Anat 2014;27:14-19.

6 Jay V: A portrait in history. The anatomical legacy of Dr Sömmerring. Arch Pathol Lab Med 1999;123:762.
7 Soemmerring ST: Über das Organ der Seele. Konigsberg F, Nicolovius, 1796 (cited by Riese.9).

8 Smith CU, Frixione E, Finger S, Clower W: The Animal Spirit Doctrine and the Origins of Neurophysiology. New York, Oxford University Press, 2012.

9 McHenry LC: Garrison's History of Neurology. Springfield, Charles C Thomas, 1969, pp 55-93.

10 de Foramine Centrali Limbo Luteo cincto Retinae Humanae. Commentationes Societatis Regiae Scientiarum Gottingensis, 1799, xiii:3; in Mackenzie W (ed): Diseases of the Eye. London, Longman 1840, p xxxii.
11 Vicq d'Azyr F: Traité d'Anatomie et de Physiologie, Tome Premier: Anatomie et Physiologie du Cerveau. Paris, Didot, 1786.

12 Riese W: The 150th anniversary of S. T. Soemmerring's organ of the soul; the reaction of his contemporaries and its significance today. Bull Hist Med 1946;20:310321 .

13 Biography of soemmering. Lancet $1830 ; 14$; 248-250. 